NBER WORKING PAPER SERIES

\title{
A COMPARISON OF THE UNITED STATES \\ AND CANADIAN BANKING SYSTEMS \\ IN THE TWENTIETH CENTURY: \\ STABILITY VS. EFFICIENCY?
}

\author{
Michael D. Bordo \\ Hugh Rockoff \\ Angela Redish
}

Working Paper No. 4546

\section{NATIONAL BUREAU OF ECONOMIC RESEARCH 1050 Massachusetts Avenue \\ Cambridge, MA 02138 \\ November, 1993}

Paper prepared for the Conference on Anglo-American Finance: Financial Markets and Institutions in 20th-Century North America and the U.K. New York University Salomon Center, New York City. December 10, 1993. This paper is part of NBER's research program in Monetary Economics. Any opinions expressed are those of the authors and not those of the National Bureau of Economic Research. 


\title{
A COMPARISON OF THE UNITED STATES AND CANADIAN BANKING SYSTEMS \\ IN THE TWENTIETH CENTURY: STABILITY VS. EFFICIENCY?
}

\begin{abstract}
This paper asks whether the vaunted comparative stability of the Canadian banking system has been purchased at the cost of creating an oligopoly. We assembled a data set that compares bank failures, lending rates, interest paid on deposits and related variables over the period 1920 to 1980. Our principal findings are that: (1) interest rates paid on deposits were generally higher in Canada; (2) interest income received on securities was generally slightly higher in Canada; (3) interest rates charged on loans were generally quite similar; (4) net rates of return to equity were generally higher in Canada than in the U.S.
\end{abstract}

Michael D. Bordo

Department of Economics

Rutgers University

New Brunswick, N.J. 08903

and NBER

Angela Redish

Deparment of Economics

University of British Columbia

Vancouver, B.C. V6T 1Y2

CANADA
Hugh Rockoff

Department of Economics

Rutgers University

New Brunswick, N.J. 08903

and NBER 


\section{Introduction}

One of the most important functions of economic history is the isolation of natural experiments that can help resolve theoretical and policy debates among economists. This paper illustrates this point by showing how a long-term comparison of banking in the United States and Canada can clarify a number of issues related to the appropriate role of government in the regulation of banking.

In the past two decades a major policy debate has raged in the United States over reforming the banking system. Several problems in the American banking system have been identified. These include: (1) restrictions on the activities banks can engage in (in part a consequence of the Glass-Steagall Act (1933) separation of commercial from investment banking); (2) limits in certain states on the number of branches a bank can have, (3) limits on interstate branching, and (4) deposit insurance.

The Canadian banking system, characterized since the turn of the century by nationwide branch banking, a small number of banks and a large number of branches, has often been viewed, because of the advantages of diversification, as superior to the American system of unit (or state branching restricted) banking. (Calomiris, 1992; White, 1983; O'Driscoll, 1988). Indeed, the Canadian banking system has been presented as a possible role model for the United States.

The Canadian experience has been one of considerable stability. There has been only one major failure since World War I, (the Home Bank in 1923) and there were no failures during the Great Depression. There have been, however, a large number of mergers and branch closings, especially during the Depression. It has been argued that many more failures would have occurred if mergers between strong and potentially insolvent banks had not been arranged.' In addition, some believe that the Canadian banking system in the Great Depression was technically insolvent but that it was propped up by an implicit guarantee by the Canadian government (Drummond, 1991; Krysanowski and Robers, 1993)..$^{2}$

In contrast, the American system has been characterized by a number of periods of instability. Rates of bank failures were high in the 1920 s and, of course, the entire system collapsed during the 1930s. Federal deposit insurance established in 1934 seemed to cure the problem for a time, but then it reemerged in the 1980s. And in the early 1990s some observers came to believe that the expansion of 
bank credit was being unduly restricted by efforts to insure stability through increased regulation of bank capital.

There is a difference, however, between the way American and Canadian observers view the two systems. American observers have argued that the difference in stability is a strong argument for adopting a variant of the Canadian system; that is to permit American banks to branch nationwide. Canadian observers, however, argue that the greater stability of the Canadian system comes at the expense of oligopoly and undue concentration of economic power as a result of high barriers to entry, including minimum capital requirements (a multiple of those in the United States) and a costly chartering provision (Bond, Shearer and Chant, 1984; Shearer, 1992; Porter Commission, 1964). Indeed, by 1966 five of the eight chartered banks held $90 \%$ of bank assets. Non-price competition, collusive rate setting and other restrictive practices, it is believed made consumers of banking services in Canada worse off than their American counterparts. Moreover, as a result of too few resources in banking, it is argued, the chartered banks earned monopoly profits.

Despite the divergent regulatory environments in the two countries, and despite the very different outcomes, there have been few studies that attempt to compare the two systems over a long period of time. This is unfortunate because the comparison between the two banking systems holds much else constant. We have two countries at comparable levels of economic development and with similar cultural, political, and social traditions. If it could be shown that the banking system in one country performed better than the other, there would be a strong prima facie case that the difference in performance lay in the regulatory system rather than some other part of the economic or social environment.

Our paper seeks to compare the two systems over the period 1920 to 1980 along two key dimensions: stability and efficiency. The choice of dates is dictated by the availability of comparable data in the two countries. However, the terminal dates clearly demarcate a period in which the contrast between the systems was at a maximum. By 1920, the full-fledged Canadian nationwide branch banking system was in place and few changes in structure occurred until the 1967 revision of the Bank Act. Both the 1967 and 1980 Bank Acts drastically changed the Canadian banking environment by allowing 
competition in banking services by non-bank financial intermediaries, by permitting entry by foreign banks, by instituting deposit insurance, and by proscribing many oligopolistic practices.

In the United States the dual banking system (national and state banks) was in full force by 1920 (White, 1983). The McFadden Act of 1927 crystallized a system in which each state had its own banking system. Beginning in the later 1970 s regulations were eased and the system began moving in the direction of a nationwide branch banking system like Canada's. Individual states began permitting more intrastate branching. As of 1990 only one state, Colorado, still completely prohibited branch banks. In addition, banks found ways around the restriction on interstate branching through the development of bank holding companies. Legal exceptions were made for banks acquiring failed banks and savings and loans in other states. Finally, and most important, a number of states, through reciprocal legislation, created regions in which banks were permitted to branch across state lines. By 1991 only Hawaii and Montana denied entrance to banks from all other states. Still, the United States remains far from a system in which banks are free to establish branches, acquire existing banks, and merge with other banks throughout the country as they wish.

The Canadian banking system during our period was both a branch banking system and an oligopolistic system (defined as a small number of banks), and ideally one would want to control for these characteristics separately. It might appear that the period 1870-1920, when the Canadian system was a branch banking system with up to 51 banks would offer such a comparison. However, the rapid contraction of the system after 1900 (described in Section 2 below) suggests that, at least given the technology of the era, and the scale of the Canadian market, branch banking in the absence of regulatory barriers would be oligopolistic. Our goal is to determine whether the oligopolists were able to use their combined market power.

We begin our analysis with a comparison of bank failures. We then present data relevant to the efficiency issue: (1) the rate of interest paid on deposits, (2) rates charged on loans, (3) net returns on equity. Comparisons reveal that (1) rates of interest paid on deposits in the two countries are very similar, (2) rates charged on loans in the two countries are very similar, (3) rates of return on equity, however, were somewhat higher in Canada, for most of the period covered. These simple comparisons 
are then followed by detailed analysis of possible sources of difference between rates of return on equity based on balance sheet identities. Although we have not pinned down all the sources of differences in the net rates of return to equity, preliminary analysis suggests that the greater degree of stability of the Canadian system allowed banks to structure their portfolios in more profitable ways.

Section 2 describes the history of the banking systems of the two countries. It shows that the difference between the systems was the result of different time-dependent paths resulting in part from the underlying political structure. The great divergence in the regulatory system does not itself seem to be the result of any obvious economic difference between the two countries. Section 3 describes the data. Section 4 presents evidence on stability. Section 5 presents evidence on the efficiency of the two country's banking systems and attempts to explain the differences found in the net rates of return on equity. Section 6 contains a short conclusion and a discussion of future research plans.

\section{Divergent Paths}

The structure of the American banking system which is unique among the industrial nations of the world -- there were about 12,000 banks in the United States in 1990 - is the result of the federal system of government, and the jealousy with which states have guarded their privileges. Before the Civil War commercial banks were chartered by state governments (with the exception of the First and Second Banks of the United States -- both of which were terminated). Some states, particularly in the South, permitted branch banking, but many states permitted only unit banks or severely limited branching. States also excluded branches of banks chartered in other states.

The antagonism in many states toward branches from other states and toward internal branching was the result of numerous causes. Partly it reflected a general fear of "monied interests." Partly it reflected the desire of each state to maximize its own political capital and in many cases its own revenue by restricting the supply of bank charters. But in many cases, it reflected the political pressures that existing banks could bring to bear to prevent legislative changes that would permit competition.

In 1863 during the financial turmoil of the Civil War the United States passed a National Banking Act under which the federal government could establish banks. A federal agency was set up, run by the Comptroller of the Currency, to issue charters and administer various regulations. It was hoped that all 
of the existing state banks would convert to national status. But this did not happen. The tax on state bank notes that had been counted on to drive the state banks into the national system proved less effective than intended. Many state banks found that they could do well by relying solely on deposits. The regulations imposed on state banks, moreover, were often less onerous than the regulations imposed on the national banks, providing an offset to the greater prestige that adhered to a national charter. Over time, as deposit banking expanded, the state systems grew and came to rival the national system.

Gradually, successive Comptrollers of the Currency developed the doctrine that the national banks were subject to the same restrictions with regard to branching as the state chartered banks in the state where the national bank was located. This doctrine was codified in the McFadden Act of 1927. The result was the "dual banking system" as it came to be called. Each state had a distinct banking system. The rules on branching varied from state to state. Some, such as California, permitted statewide branch banking and systems analogous to the Canadian system developed. At the other extreme some, such as Illinois, prohibited branch banking altogether. In the latter cases, rural areas in particular were characterized by large numbers of small vulnerable banks.

Repeatedly after the Civil War (in 1873, 1884, 1890, 1893 and 1907) the financial system was hit by panics (or "stringencies") in which large numbers of banks failed, and the public, fearing complete collapse of the system, withdrew cash. After the Panic of 1907 a National Monetary Commission was set up, and on the basis of its recommendations the Federal Reserve system was established in December 1913. The Federal Reserve, it was hoped, would prevent future panics by acting as a lender of last resort when a panic threatened, and through its regulatory activities with regard to member banks. (National banks were required to join and state banks could do so if they chose.) For a variety of reasons, however, the Federal Reserve failed to act aggressively to stem the tide of bank failures in the early 1930s, and the banking crisis of 1930-1933 turned out to be worse than any previous crisis.

New legislation was passed intended to further strengthen the system, although without attacking the fragmented structure of the system, the root cause of the problem. The link between gold and the money supply was broken (removing an important constraint on the ability of the Federal Reserve to act as lender of last resort), interest on time deposits was restricted and interest on demand deposits was 
prohibited, investment banking was separated from commercial banking, and a system of national deposit insurance was established. Deposit insurance was administered by the newly created Federal Deposit Insurance Corporation which was also given regulatory powers.

For a time the reformed system worked well. Bank failures were infrequent after 1934, and the public was satisfied that a remedy at last had been found for the instability of the banking system. In the 1970s, however, rising inflation created new strains, and the rate of bank failures increased. The restrictions on deposit interest were particularly troublesome since inflation was raising the general level of interest rates. In 1980 Congress passed the Depository Institutions Deregulation and Monetary Control Act which, among other things, created deposit accounts on which banks could pay competitive rates of interest.

In recent years recognition has been growing that the fragmented structure of the system is a drawback both because it weakens the banking system internally and because it makes it harder for American banks to compete in international markets. As a result, traditional restrictions on branch banking have been weakened. Exceptions have been made for banks purchasing insolvent banks in other states. Bank holding companies have been permitted to circumvent restrictions by carrying on a restricted range of activities in other states. Chains of banks under common ownership have been able to provide some of the economies of scale possible with branching. And some states have passed laws allowing branches of banks chartered in other states that have made reciprocal arrangements, thus creating regions of the country in which banks are relatively free to branch across state lines. Nevertheless, the banking system of the United States remains greatly fragmented when compared with other industrial nations, and especially with her neighbor to the Norh.

The first bank to open in Canada (or rather the colonies that became Canada) was the Bank of Montreal which was chartered in 1821 . The charter permitted it to open branches, make loans against real bills, buy securities, issue notes and hold deposits. Since that time branching has remained a feature of Canadian banking, (in 1980 there were 11 banks and 7414 branches) but much else has changed. Although relative to the United States, Canada has always had a small number of banks, the number has declined dramatically from the historical maximum of 51 banks in 1874 . Between 1874 and 1900 the 
number declined to 35 , primarily reflecting 17 insolvencies, and by 1925 there were only 11 banks remaining, mainly as a result of 27 mergers. The shift from insolvency to amalgamation reflected a legislative change that made it possible for banks to merge without having a specific act of parliament. The shift, together with considerable anecdotal evidence, has led many observers to argue that prior to the mid-20s the Canadian system was not particularly stable.

In addition to the absence of branching restrictions, other regulatory restrictions have been less severe in Canada. The Office of the Inspector General of Banks began bank inspections in 1924 following the failure of the Home Bank, but even in 1980 had only 7 inspectors. In that same year, the office of the Comptroller of the Currency which regulates national banks had 2089 examiners (White, 1992, p. 92) -- and this comparison excludes examiners based at the Federal Deposit Insurance Corporation, and in state regulatory agencies. The introduction of the Bank of Canada in 1935 led to required reserves and the phasing out of privately issued bank notes.

In 1962 the federal government appointed a Royal Commission on Banking and Finance (the Porter Commission) whose report in 1964 argued that the concentration in the Canadian banking industry had imposed considerable costs on Canadians. Testimony by bankers stated that they had discouraged price competition -- both for deposits and on loans - although they emphasized the fierceness of non-price competition. The Commission's report advocated increasing the extent of competition in the banking system, and leveling the playing field between banks and near-banks.

Although jurisdictional disputes (near-banks are primarily under provincial jurisdiction) prevented adoption of some of the Commission's recommendations, many were adopted. Reserve requirements were lowered. Lending activities, which had been expanded in 1954 to include insured mortgages and chattel mortgages, were further broadened to include all mortgages. Lending rate ceilings which had been reduced from 7\% 10 6\% in 1944 were removed in the 1967 revisions to the Bank Act. Also in 1967 the federal government introduced compulsory deposit insurance (the CDIC). Since rates were not risk adjusted and near-banks were also eligible to join, this increased the competition for the chartered banks. In 1980 the privately owned and operated Canadian Payments Association took over operation of the clearing house from the Canadian Bankers' Association as a result of the government's insistence that the 
non-bank depository institutions have equal access to the payments system.

\section{The Data}

We have collected annual data for both the United States and Canada covering primarily the period 1920 to 1980 , the period when the contrast between the Canadian and American systems is greatest. For the United States we have concentrated on the national banks, primarily because good balance sheet and income data exist from the founding of the system in 1863 up to today, but also because the National Banks are generally larger and thus resemble the Canadian banks. The United States data are available in the Annual Reports of the Comptroller of the Currency, although many of the series we use are reproduced in Historical Statistics of the United States and All Bank Statistics. The Annual

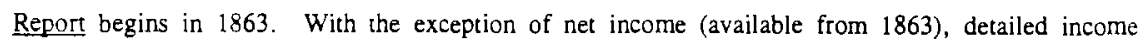
statement data is not available until after 1919. Specifically, "Interest and Fees (Discount) on Loans" begins in 1919, and "Interest and Dividends on Bonds, Stocks and Other Securities" begins in 1927. This latter category, is an aggregation of income from United States government securities and other securities consisting mainly of obligations of state and political subdivisions in the United States. These subdivisions are identified after 1945. "Interest Paid on Total Deposits" is available after 1929.

Balance Sheet data is available since 1863. Categories of interest here include "Total Loans," "Total Deposits," and "Total Capital." The disaggregation of "Total Deposits" into time, demand, and government deposits is made available, discontinuously, after 1929. "Total Capital" (what we refer to as equity) is defined as preferred, common and capital stock, surplus, undivided profits and reserves for contingencies. Return ratios are constructed by dividing interest income (expense) by the asset (liability) responsible for generating the income (expense). Real ratios are constructed by subtracting changes in the Consumer Price Index. The following balance sheet shows the breakdown we have worked with. 


\begin{tabular}{||l|l|}
\hline \multicolumn{2}{|c|}{ Bank Balance Sheet } \\
\hline \hline Assets & Liabilities and Capital \\
\hline $\mathrm{R}=$ reserves & $\mathrm{D}=$ Deposits \\
\hline $\mathrm{S}=$ Securities & $\mathrm{OL}=$ Other Liabilities \\
\hline $\mathrm{L}=$ Loans & $\mathrm{K}=$ Capital \\
\hline $\mathrm{OA}=$ Other Assets & \\
\hline $\mathrm{A}=$ Total Assets & Total Liabilities and Capital \\
\hline
\end{tabular}

For example, our estimate of the average interest on loans is computed by dividing income from loans from the income statement by total loans (L) from the annual balance sheet. In some cases it would be desirable to have more disaggregated data -- to be able to distinguish the interest on demand deposits from the interest on time deposits, for example. Nevertheless, even the broad categories that we are able to collect consistently over the period make possible some interesting comparisons between the United States and Canada.

The data for Canada are similar, so similar in fact as to suggest that the assemblers of the Canadian data assumed that users would want to make comparisons with the United States. Each Canadian bank is required to file monthly balance sheets with the government which publishes them in the Canada Gazette. Historical (aggregate) data are reprinted in the Historical Statistics of Canada (1983) and, for more recent years the Bank of Canada Review. Since 1929 income and expenses accounts for the banks are reported annually and the aggregated data are available in the Historical Statistics of Canada and the Bank of Canada Review (February 1993).

\section{Stability}

The relative stability of the Canadian banking system during the period we cover is well known. Between 1920 and 1980, only one major Canadian bank failed: The Home Bank in 1923 with a capital (paid in plus reserve) of $\$ 2.5$ million, about 1 percent of total bank capital at the time. The failure of 
the Home Bank was the result of excessive lending on western real estate, whose value collapsed in the deflation of 1920. During the 1930s a number of branches were closed, and closings may have been analogous in some ways to the bank failures that occurred in the United States. But depositors never lost any money and borrowers could tum to other branches of the same institution, although some of the long term ties between borrowers and their local branches were severed.

In recent years there have been a number of troubling failures suggesting something of a convergence in the levels of stability in the two systems. Two small banks in Alberta failed due to concentration on oil related lending. There have also been a number of failures among the Canadian Trust companies, analogous to the failures in the U.S. among the Savings and Loans. But there have been no failures among the large banks with nationwide branch systems that we focus on.

The very different picture for the United States is illustrated in Figure 1A which plots the annual percentage of insolvent national banks for the whole period since the founding of the national banking system, and Figure 1B which plots the same ratio for the period since 1935. The depression of the 1890s, the high rate of failure (mostly among rural banks) in the 1920s, the catastrophe of the 1930s, the relative stability during most of the postwar period, and the increased difficulties in recent years are readily apparent in the figures.

Typically, it is the smaller national banks that fail, so the picture is somewhat changed if we turn to Figure $2 \mathrm{~A}$ which plots the ratio of the capital of insolvent national banks to capital in all national banks for the period 1920-1990, and Figure 2B which plots the same ratio for the period after 1935. The depression of the 1930s still stands out in sharp relief, but the banking difficulties of the late 1980s fade into the background. The reason is simply that insolvencies in recent years have been confined to very small national banks, state chartered banks, and the savings and loan associations. Larger national banks have been exempt. The peak in 1974 is the failure of the Franklin National Bank, a large bank with branches in New York City and Long Island. 
But why should we be so concerned about differences in bank failure rates? In general we want entrepreneurs to take risks, and if they do, we expect that some projects will turn out badly, and that some businesses will fail. So in most industries we do not want a government policy that aims at zero failures. Nevertheless, it has long been accepted that banking is different, and that for several reasons a major goal of government policy should be reducing the rate of bank failure to near zero. For one thing, a bank failure may disrupt a wide range of local businesses that depend on the bank for credit or other services. Second, a bank failure may hurt a large number of relatively poor depositors, so the welfare effects of bank failures may be more troubling than the welfare effects of failures of similar magnitude in other industries. Finally, of course, there is the possibility that a bank failure could set off a panic producing a cumulative contraction of money and credit. The establishment of deposit insurance in both countries, and of central banks with the authority to act as lenders of last resort, reflect the public attitude toward bank failures, and have served to mitigate the differences in failure rates in the two countries since the 1930s. Still, to the extent that a difference remains, these arguments strongly suggest remaking the U.S. banking system in the Canadian image.

But, as we noted above, the Canadian system is characterized by a small number of banks, that at least at first glance may have the ability to collude and exploit the public. We now turn to a comparison of lending and other activities in the two systems.

\section{Efficiency}

Economists generally think of banks as intermediaries that issue short-term liabilities, demand and time deposits, and then invest in longer term liabilities, govemment or private securities and various types of individualized loans. The profits of the bank are generated by the difference between the rate of return paid on deposits and the rate received on longer term investments, and from the bank's specialized skill in placing and administering individualized loans. This picture is, to be sure, oversimplified. Modern banks engage in a wide range of other activities -- managing trust funds, issuing letters of credit, selling 
foreign exchange, and so on -- and in some cases these activities may overshadow more traditional forms of banking. It is also, we hasten to add, a picture that applies more to banks in the English speaking world than to banks in other areas. But in comparing Canadian and United States banking it makes sense to start with the traditional simplified view of a bank and see how far that takes us.

Even in this simplified model there are several distinct areas in which monopoly power could make itself felt. Below we will consider three separate markets: (1) the market for deposits, (2) the market for securities, and (3) the market for loans. We will then look at the bottom line, the net rate of return to capital. Presumably, no matter the market in which banks exercise monopoly power, it should show up, in the end, in the net rate of return to equity.

Monopoly power could make itself felt through the exploitation of depositors. A banking cartel could pay lower interest rates than those that would emerge from the free play of economic forces. This, of course, is not the only possibility. It may be that a branch banking system would provide competition in small markets when a unit banking system would not.

On the other hand, we must also take regulation into account. From 1934 to 1980 American deposit interest rates were tightly regulated. Interest on checkable deposits was entirely prohibited, and interest on time deposits was subject to a ceiling that was sometimes below market rates. These regulations were imposed after the banking crisis of the early 1930s. Undoubtedly, bankers sought these restrictions in order to increase their profits, but the argument they made - that "excessive" price competition during the twenties had contributed to the crisis by forcing banks to hold "excessively" risky portfolios -- fell on receptive Congressional ears. We would expect that what was in effect a government run cartel would have been more efficient at exploiting bank depositors than a private cartel. Figure $3 \mathrm{~A}$ plots nominal deposit interest rates in Canada and the United States; Figure 3B plots real deposit interest rates, calculated by subtracting the annual percentage change in the consumer price index from the nominal return. Canadian nominal rates are above United States nominal rates throughout. The gap begins 
to widen in the nineteen sixties. The freer Canadian rates moved up with inflation, while the more heavily regulated American rates did not. Evidently, the United States government enforced cartel was more potent than the Canadian system that permitted a small number of highly branched banks freedom to set their own rates.

As might be expected the differentials appear to be smaller when real rather than nominal magnitudes are compared. But even here the opening of the gap in the 1960s, and the sharp run up at the end of the seventies, are visible.

We expect that if the Canadian banks were exploiting monopoly power they would do so by restricting the supply of loans and raising interest rates on them. This is not, however, the only possibility suggested by the literature. It has been argued that in the United States in the nineteenth century many southern and western towns became one-bank or few-bank towns as a result of restrictions on branch banking. The result was that banks in those areas could charge monopoly loan rates (Sylla, 1969). If this situation continued into the twentieth century it is possible that U.S. loan rates might be above Canadian rates. To examine this issue we computed proxies for nominal loan rates for both countries by dividing gross loan income by total loans for both countries. ${ }^{3}$ Figure $4 \mathrm{~A}$ plots the nominal loan rates for Canada and the United States and Figure 4B plots the real loan rates. We had expected to find that Canadian loan rates would normally be above United States loan rates due to the market power of the Canadian banks. We should have had more faith in the equalizing force of competition. Generally, the two series track each other fairly closely, and in the one period in which a sustained gap opens up, from the mid-1940s to the late 1960s, it is the United States loan rate that is higher. This evidence suggests that Canadian borrowers were not being exploited by cartel-like practices of the Canadian bankers.

We have no compelling explanation for the gap that opened up from the mid-1940s to the late 1960s. One possibility is that the Canadian ceiling on bank lending rates which, as we noted above, was 
reduced from $7 \%$ to $6 \%$ in 1944, but then removed in the 1967 revisions to the Bank Act, kept Canadian rates below their equilibrium level.

The gap is less visible in Figure 4B. Partly this is due to the change in scale. The postwar movements (and differences) in real rates are all small compared with the violent movements in the 1930s and 1940s. But movements in inflation rates also eliminate the gap in some of the early years, so that it does not open up clearly until the mid-1950s. The examination of the real rates, however, lead us to the same conclusion with regard to the role of monopoly power: there is no evidence of a sustained differential in favor of the Canadian banks that would indicate significant welfare losses from monopoly behavior on the part of the Canadian banks. ${ }^{4}$

In addition to not accounting explicitly for local monopoly power in the United States, our comparison of bank lending rates may also be biased by not accounting for the fact that U.S. banks operate in a heterogenous mix of loan and deposit markets, ranging from the large corporate market to commodity markets that are more protected from direct competition with the open markets. Though our use of the mean loan rate could account for each source of bias taken in isolation it may not account for both. One way to deal with these issues -- a subject for further research - is to compare all U.S. banks (state, national, savings and loan and mutual savings banks) with the sum of Canadian chartered banks and near banks (the trust companies) or else to compare U.S. money center banks with Canadian chartered banks

Our estimates of bank lending rates, we must also admit, may be biased downward by the holding of compensating balances." If, for example, a bank required a borrower to keep on deposit funds equal to 20 percent of the loan, and if the borrower would not otherwise hold deposits of that amount in any bank, then a nominal rate of 10 percent on the loan, would be equivalent to a true rate of 12.5 percent (10/[1-.2]). This is most likely to have been a problem in Canada during the period from the mid-40s to the mid-1960s when the 6 percent usury ceiling was in place. 
Surveys of bank lending practices in the United States (Baxter and Shapiro, 1964; Burns, 1972; and Mahoney 1988) have shown that compensating balance requirements are substantial, and have changed over time. The mere existence of compensating balances, however, does not necessarily imply that our estimates are in error because compensating balances can be used for a wide variety of purposes besides hiding increases in lending rates. For example, compensating balances can be used to forge and maintain long-term relationships with customers. And they can be used by a bank to monitor the behavior of their borrowers. In either case, if a customer would have maintained the deposit in the lending bank or with a competitor in the absence of the compensating balance requirement, the compensating balance cannot be viewed as increasing the effective loan rate to the extent illustrated by the numerical example given above. Compensating balances may also be used for other purposes such as compensating banks for providing lines of credit or, during some periods in U.S. history, paying interest on deposits indirectly by providing lower loan rates for depositors. For further discussion of the many uses of compensating balances see Gilbert (1977), Meinster (1977), Duca (1991), and the references cited there.

Unfortunately, we have not been able to think of any practical way of estimating the probable extent of the bias. Until further information on the nature and extent of compensating balances becomes available, this point must simply be held in mind as a possible qualification of our results.

We did not expect major differences in rates of return to the security portfolios of the banks. The securities held by banks, typically, are traded on highly competitive domestic and international markets. It seemed unlikely that the Canadian banks would be able to exercise sufficient market power to influence the rates of return.

Figure 5A plots nominal returns to the security portfolios, and Figure 5B, the real returns. There is evidently a small but persistent gap between the nominal retums on Canadian securities and the nominal Ieturn on U.S. securities throughout the period we cover. The gap is less persistent when we examine real rates in Figure 5B, but it is still visible throughout most of the postwar period. There are severa! 
possible explanations: (1) differences in the risk structure of the security portfolios, (2) differences in country risk. But we have not pursued this difference since it did not seem directly related to the issue of monopoly power.

Our examination of the spreads (rates charged less rates paid), to sum up, turned up little evidence that cartel behavior on the part of Canadian banks allowed them to exploit their customers, at least in comparison with U.S. banks. We therefore expected that when we turned to the net rate of return to equity, there would be little persistent difference.

Figure 6A plots the nominal return to bank equity (net returns divided by total capital); and Figure 6B plots real returns. A consistent gap, however, emerges in favor of the Canadian system. Except for a segment in the 1950s and 1960s (which corresponds to the time when United States loan rates were relatively high) Canadian rates of return to equity were generally higher than American rates. ${ }^{6}$

This presented us with something of a paradox: on the one hand there is little evidence of monopoly power in Canadian loan and deposit markets and yet, on the other hand, there is evidence that Canadian banks often earned higher net returns on equity. On the basis of comparisons of the balance sheets we concluded that it could be explained, at least proximately, by the structure of bank balance sheets. Table 1 below shows two key ratios at decade intervals. Notice that in every year the Canadian banks devoted a larger proportion of their assets, usually a considerably larger proportion, to loans. The Canadian banks, moreover, were more highly leveraged than U.S. banks. In some years the difference was striking. In 1950 for example the Canadian leverage ratio was almost twice the U.S. ratio.

To test whether balance sheet differences explain the gap between net rates of renurn on equity we computed two counterfactual gaps. In one we kept the U.S. balance sheet structure but changed the "prices" -- we used Canadian loan rates, security rates, deposit rates, and expense ratios. In the other we kept U.S. prices but changed the balance sheet -- we used Canadian loan-asset, security-asset, and assetcapital ratios. 
More formally we used the following identity derived from the definition of the rate of return on equity and the balance sheet identity.

(1) $\operatorname{ROE}=(\mathrm{A} / \mathrm{K})^{*}\left\{\mathrm{r}^{*}(\mathrm{~L} / \mathrm{A})+\mathrm{rs} *(\mathrm{~S} / \mathrm{A})-\mathrm{rd} *(\mathrm{D} / \mathrm{A})-\mathrm{x}\right\}$

where ROE is the rate of return on equity
A is total assets
$\mathrm{K}$ is total equity
$\mathrm{rl}$ is the rate of return on loans
rs is the rate of return on securities
$\mathrm{L}$ is total Loans
$S$ is total Securities
rd is the rate paid on deposits
$D$ is total Deposits, and

$\mathbf{x}$ is residual costs and earnings per dollar of assets.

We then defined three gaps. The actual gap is the Canadian ROE less the U.S. ROE. The price gap is the U.S. ROE with $\mathrm{rl}, \mathrm{rs}, \mathrm{rd}$, and $\mathrm{x}$ changed to the Canadian levels less the actual U.S. ROE. The balance sheet gap is the U.S. ROE with A/K, L/A, S/A, and D/A changed to the Canadian levels. To put it somewhat differently, the price gap and the balance sheet gap can be thought of as the determinants of the actual gap. The price gap and the balance sheet gap, as we have defined them, however, do not sum exactly to the actual gap, because of interaction effects. The results of these computations are displayed in figures 7A (nominal) and 7B (real).

The overall picture is clear. Balance sheet differences greatly favored the Canadian banks. If the only differences between Canadian banks and U.S. banks were their leverage, loan-asset, security-asset, and deposit-asset ratios, the gap between the Canadian ROE and the U.S. ROE would have been even larger than it actually was. Price differences, on the other hand, worked against the Canadian banks. If 
the only differences between the Canadian banks and U.S. banks were their rates of return on loans and securities, their rates paid on deposits, and their administrative costs, the Canadian ROE would have been below the U.S. ROE.

The relative importance of balance sheet and price variables, however, changed over time. During the period, 1929-1944, there was little difference in rates of return to earning assets and deposit rates, so the effect of the Canadian balance sheets (high earning asset ratios, and high leverage) was to raise the actual Canadian ROE above the US ROE. During the period, 1945 - 1966 especially after 1955, the two determinants offset each other. The loan rate in Canada was lower than in the US, possibly because of legal restrictions on lending rates, and this offset the positive effects of the Canadian balance sheets. The result was little difference in ROEs. During the first part of the period 1967-1979 an improvement in Canadian spreads compared with U.S. spreads (driven by rising Canadian loan rates) pushed the Canadian ROE above the US ROE. A deterioration in Canadian spreads compared with the U.S. (driven by higher deposit rates in Canada) then set in, but this was more than offset by a rapid increase in Canadian leverage, thus keeping the Canadian ROE above the US ROE for the remainder of the period.

To explain these results we would suggest three related factors. (1) Regulatory differences. U.S. national banks were subject to higher reserve requirements than Canadian banks until the 1960 s. U.S. required reserve ratios at national banks for demand deposits generally averaged between 7 and 9 percent until the famous doubling of reserve requirements in 1936 and 1937, it then remained in the neighborhood of 15 percent until the mid-1950s. (Cagan, 1965, p. 361). From 1935 to 1954 the required reserve ratio in Canada, on the other hand, was five percent on Canadian dollar deposits. In 1954 it was raised to 8 percent, still well below the U.S. level. In 1968, however, Canadian reserve requirements were increased to 12 percent on demand deposits, to 4 percent on time deposits, and a secondary reserve requirement against foreign and domestic deposits was introduced -- changes which appear to have brought Canadian and U.S. standards roughly into line. 
During part of the period, moreover, restrictions on U.S. deposit rates, although they worked to increase profit rates, may have made U.S. banks sensitive to the danger of losing deposits when market rates rose, forcing them to maintain more liquid reserves. In addition, debt-equity ratios were lower in the U.S., partly as a result of regulation.

(2) Economies of scale. It may be that Canadian banks enjoyed economies of scale that permitted them to reduce their holdings of liquid assets compared with American banks. A rural branch of a bank in Canada, for example, might have been able to concentrate on lending, while a corresponding rural independent bank in the United States might have been forced to hold relatively more liquid reserves because it was not able to rely completely on other banks or the Federal Reserve when it needed reserves. Recently, Nathan and Neave (1992) have provided some evidence for this explanation. ${ }^{7}$

(3) Stability. Finally, the low risk of failure in Canada might have made it possible for the Canadian banks to hold smaller amounts of non-interest bearing assets, and to proceed to higher assetequity ratios. The regulatory differences discussed above under (1), moreover, were in turn the result of attempts to achieve stability without upsetting the traditional industrial structure of U.S. banking. Reserve requirements and similar controls, in other words, were second best attempts to achieve stability that reduced the ability of U.S. banks to serve their customers effectively.

\section{Conclusion}

This exercise addresses the question of whether the vaunted comparative stability of the Canadian banking system has been purchased at the cost of creating an oligopoly that exploits bank borrowers or other users of banking services. We assembled a data set that makes possible comparisons of bank failures, lending rates, interest paid on deposits, and related variables over the period 1920 to 1980 when the contrast between the two systems was at a maximum. Our principal findings are that (1) interest rates paid on deposits were generally higher in Canada in real and nominal terms, (2) interest income received on securities was generally slightly higher in Canada in nominal and real terms, (3) interest rates charged 
on loans were generally quite similar in nominal and real terms except in one period when loan rates were higher in the United States, and paradoxically, (4) net rates of return to equity were generally higher in Canada than in the U.S. in nominal and real terms.

We then conducted an analysis of the difference in net rates of return to equity. Our analysis suggests that the higher rate of return to equity in Canada was due to the higher proportion of Canadian portfolios devoted to lending and to the higher asset-equity ratios of the Canadian banks.

Tentatively. we have attributed the differences between the U.S. and Canadian balance sheets to regulatory differences, economies of scale, and the generally greater stability of the Canadian system. The last factor may well have been the most important: because the threat of failure was low banks could reduce reserve ratios and increase leverage without alarming customers, or provoking regulatory restrictions. The difference in net rates of return, in other words, might have been a return to an unmeasured component of Canadian bank capital -- their reputation for soundness. But to reiterate, this is partly conjecture. Further research is needed to clarify this explanation and to distinguish it from other candidates. What is clear at this point is that there is no evidence that cartel behavior among Canadian banks created gross differences in lending rates or other measures of bank behavior that would imply that the Canada paid a high price for the stability it enjoyed relative to the U.S. This conclusion, moreover, is reinforced by recent studies of Canadian banking that use very different methodologies (Nathan and Neave, 1989; Shaffer, 1993).

In addition, we should note that our brief for the Canadian system takes the existing U.S. banking system as the relevant alternative. A considerable number of studies of U.S. banking markets, have shown that it is reasonably competitive. (Gilbert 1984, which surveys a considerable number of studies, and Shaffer and DiSalvo 1991). So the finding that Canadian users of bank services were treated about as well as their neighbors to the south over the period 1920-1980, while experiencing a much higher level of bank stability, speaks well for the Canadian system. But of necessity studies of 
competition in U.S. banking markets do not address the effects of permitting unlimited merging, acquiring, and branching. It is possible that the massive reorganization resulting from such a policy would produce much greater efficiency in the U.S. banking system. So our comparison does not rule out the possibility of some cartel-based inefficiency in the Canadian banking system when it is compared with a hypothetical reorganized U.S. system, or, for that matter, a more open Canadian system. ${ }^{8}$

The conclusion that the Canadian banking system was both more stable and more efficient than her American counterpart raises the broader issue of which system was better for economic development. On the one hand, the Canadian branch banking system had greater lending capacity than did the U.S. unit (restricted branching) system, but the latter substituted for this deficiency by developing more open and deep capital markets. Both systems in turn possessed advantages and disadvantages compared to the European 'universal' banking model. Each banking system represents a different mix of 'market-based' and 'institution-based' financial systems. Which model is superior is an open question. 


\section{References}

Baxter, Nevins D. and Harold T. Shapiro. (1964) "Compensating-Balance Requirements: The Results of a Survey." Journal of Finance 19: 483-96.

Bodenhorn, Howard and Hugh Rockoff (1992). "Regional Interest Rates in Antebellum America." In Claudia Goldin and Hugh Rockoff, eds., Strategic Factors in Nineteenth Centurv American Economic History: A Volume to Honor Robert W. Fogel. Chicago: University of Chicago Press.

Boyd, John H. and Stanley L. Graham (1991). "Investigating the Banking Consolidation Trend." Federal Reserve Bank of Minneapolis Quarterly Review, Spring, pp. 3-14.

Burns, Joseph E. (1972) "Compensating Balance Requirements Integral to Bank Lending." Federal Reserve Bank of Dallas Business Review February, 1-8.

Busche, Kelly and John F. Chant. (1992) "The Imminent Failure Hypothesis in Canadian Banking." Simon Fraser University (mimeo).

Cagan, Phillip. (1965) Determinants and Effects of Changes in the Stock of Money, 1875-1960. New York: Columbia University Press for the NBER.

Calomiris, Charles. (1992) "Regulation, Industrial Structure, and Instability in U.S. Banking: An Historical Perspective." Ch. 1. in Michael Klausner, Lawrence J. White, editors. Structural Change in Banking. Homeward, Illinois:Irwin.

Davis, Lance. (1965) "The Investment Market, 1870-1914: Evolution of a National Market" Journal of Economic History, 25: 355-99.

Drummond, Ian. (199l) "Why Canadian Banks Did Not Collapse in the 1930's" in Harold James, Hakan Lindgren, and Alice Teichova (eds) The Role of Banks in the Interwar Economy: New York, Cambridge University Press, pp. 232-250. 
Duca, John V. (1992) "U.S. Business Credit Sources, Demand Deposits, and the Missing Money." Journal of Banking and Finance 16: 567-83.

Gilbert, R. Alton. (1977) "Effects of Interest on Demand Deposits: Implications of Compensating Balances." Federal Reserve Bank of St. Louis Review 59: 8-15.

(1984) "Bank Market Structure and Competition: A Survey." Journal of Money, Credit. and Banking 16:617-45.

Haubrich, Joseph G. (1990) "Nonmonetary Effects of Financial Crises: Lessons From the Great Depression in Canada." Journal of Monetary Economics 25:223-252.

James, John. (1976) "The Development of the National Money Market," Journal of Economic History 36: 878-97.

Keehn, Richard. (1975) "Market Power and Bank Lending: Some Evidence from Wisconsin, 18701900," Joumal of Economic History 35: 591-620.

Kryzanowski, Lawrence and Gordon Roberts. (1993) "The Performance of the Canadian Banking System 1920 - 1940." Journal of Money. Credit and Banking (forthcoming).

Mahoney, Patrick I. (1988) "The Recent Behavior of Demand Deposits. " Federal Reserve Bulletin 74: $195-208$.

Meinster, David R. (1977) "The Demand for Compensating Balances." Southem Economic Journal 45: $1538-46$.

Nathan, Alli, and Edwin H. Neave. (1989) "Competition and Contestability in Canada's Financial System: Empirical Results." Canadian Joumal of Economics 22: 576-94. . "Operating Efficiency of Canadian Banks." Queens University Working Paper (1992).

O'Driscoll, Gerald P., (1988) "Deposit Insurance in Theory and Practice." In Catherine England and Thomas Huertas, eds., The Financial Services Revolution. Boston: Kluwer Academic Publishers. 
Report of the Royal Commission on Banking and Finance, (Porter Commission). (1964) Ottawa:Government of Canada.

Shaffer, Sherrill. (1993) "A Test of Competition in Canadian Banking." Journal of Money Credit and Banking. 25: 49-61.

Shaffer, Sherrill and J. DiSalvo. (1991) "Conduct in a Banking Duopoly. "Federal Reserve Bank of Philadelphia, working paper 91-12.

Shearer, Ronald A., John F. Chant, David E. Bond, (1984) The Economics of the Canadian Financial Svstem: Theory, Policy and Institutions. Second Edition. Scarborough, Ontario: Prentice-Hall Canada, Inc.

Shearer, Ronald A. (1992). "The Canadian Financial System" New Palgrave Dictionary of Money and Finance. London:MacMillan.

Smiley, Gene. (1975) "Interest Rate Movements in the United States, 1888-1913. " Journal of Economic History 35: 591-620.

Sylla, Richard. (1969) "Federal Policy, Banking Market Structure, and Capital Mobilization in the United States, 1863-1913." Journal of Economic History 29: 657-86.

White, Eugene N. (1992) The Comptroller and the Transformation of American Banking, 1960-1990. Washington D.C: Comptroller of the Currency.

White, Eugene N. (1983) The Regulation and Reform of the American Banking System, 1900-1929. Princeton:Princeton University Press. 
* For excellent research assistance we would like to thank Patrick Coe, Sherrie Metcalfe, and Joseph Santos. The University of British Columbia small grants program provided financial assistance.

\section{Endnotes}

1. According to Bushe and Chant (1992), however, based on an examination of rates of return on investment between mergee and mergor banks 1900-1931, there is little evidence for the "imminent failure" hypothesis.

2. Evidence by Haubrich (1990) on the other hand, shows that though there was a significant reduction in the number of branches in Canada during the Great Depression (still less than one half the number of bank failures in the U.S.), this did not have the same deleterious effects on economic activity as Bernanke (1983) found for bank failures in the U.S.

3. Similar proxies have been widely used to estimate rates of return to bank loans in the United States in the nineteenth century. See Davis (1965), Sylla (1969), Keehn (1975), Smiley (1975), James (1976), and Bodenhorn and Rockoff (1992). The actual return on loans is not available for the nineteenth century. They have to be estimated by imputing a return to the security portfolio. For our period, however, interest on loans is available separately.

4. We also plotted a moving five year standard deviation of the loan rates - to test whether rates were more stable in one country or the other -- but there were no readily apparent differences.

5. We thank Ronald Shearer for pointing out the potential significance of compensating balances to us.

6. Some difference might have been expected on the basis of exchange rate risks or other country-related risks. For example, even during a period of fixed exchange rates long-term investors in banks would have to be concerned about furure devaluations or revaluations of the Canadian dollar. The difference in rates of return to the security portfolios (figure $5 \mathrm{~A}$ ) are likely to caprure these risks, and this difference seldom exceeded 100 basis points. The net rate of return gap, when it emerged, was often substantially 
larger. We also examined the gap in short-term government treasury bill rates, but this gap was also of much too small a magnitude to explain the gap in net rates of return to equity.

7. Although Boyd and Graham (1992) find that for the U.S., economies of scale are created by middlesized banks while most mergers occur among large banks.

8. The most likely avenue for achieving greater competition within the Canadian system would be removing restrictions on the ability of foreign banks to compete in the Canadian market. 
Tablo 1

Koy Aut Retios, 1920-1980

Year

1920

1930

1940

1950

1960

1970

1980
U.S. Loens to Amets Ratio (Percent)

$53.1 \%$

51.2

27.2

32.6

45.7

50.9

54.9

\section{Cunedien Loems to} Alacts Ratio (Perceal)

$72.7 \%$

69.1

41.9

43.6

63.6

61.2

72.1
U.S. Assets to Conedien Assets to Capital Ratio Capital Ratio

$\begin{array}{ll}8.7 & 11.6 \\ 7.2 & 10.2 \\ 10.6 & 13.4 \\ 14.5 & 27.4 \\ 12.6 & 17.0 \\ 13.7 & 21.6 \\ 18.1 & 33.4\end{array}$

Source: See Section 3. for a deacription of the deth 
Figure $1 \mathrm{~A}$

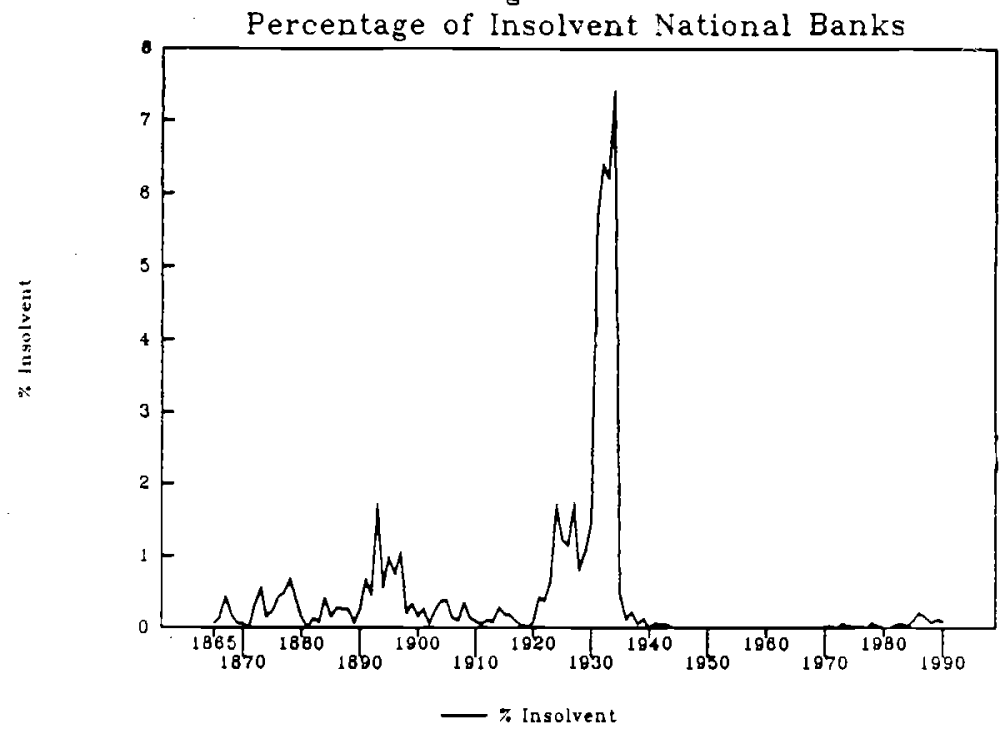

Figure 1B

Percentage of Insolvent National Banks

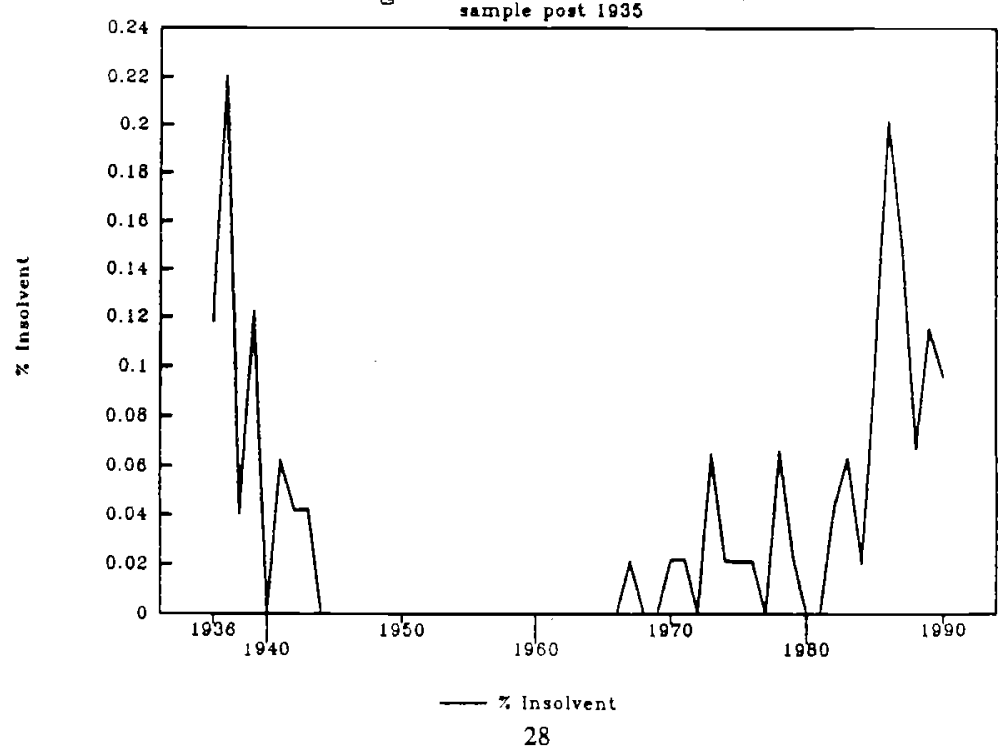


Figure 2A

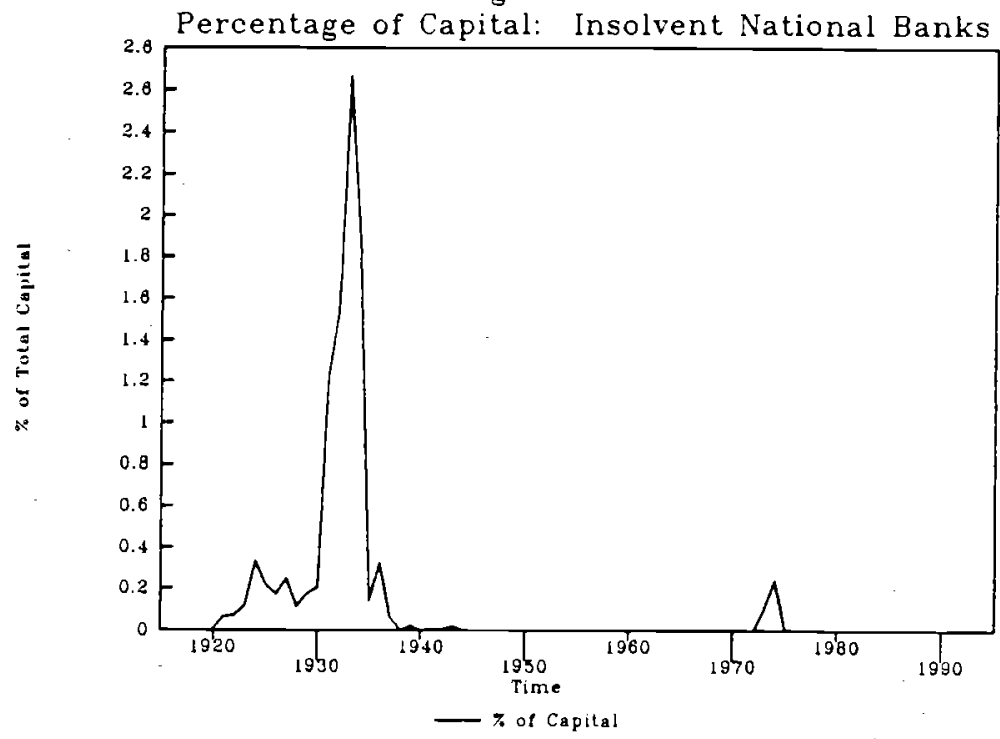

Figure 2B

Percentage of Capital: Insolvent National Banks

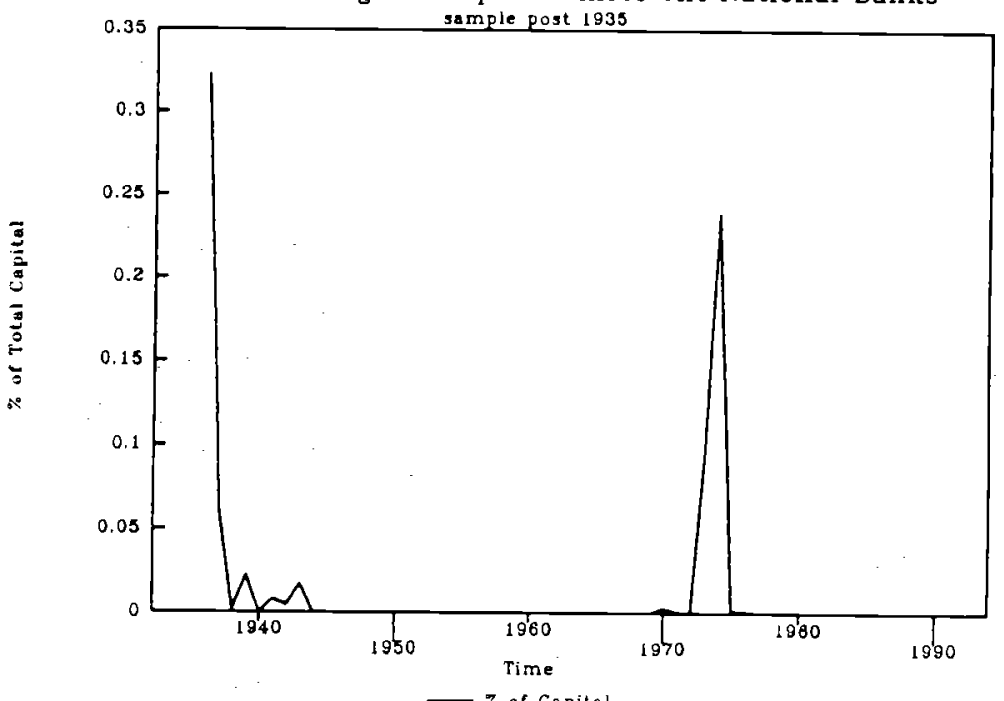


Figure $3 \mathrm{~A}$

Interest Rate on Deposits

Canada v. U.S.

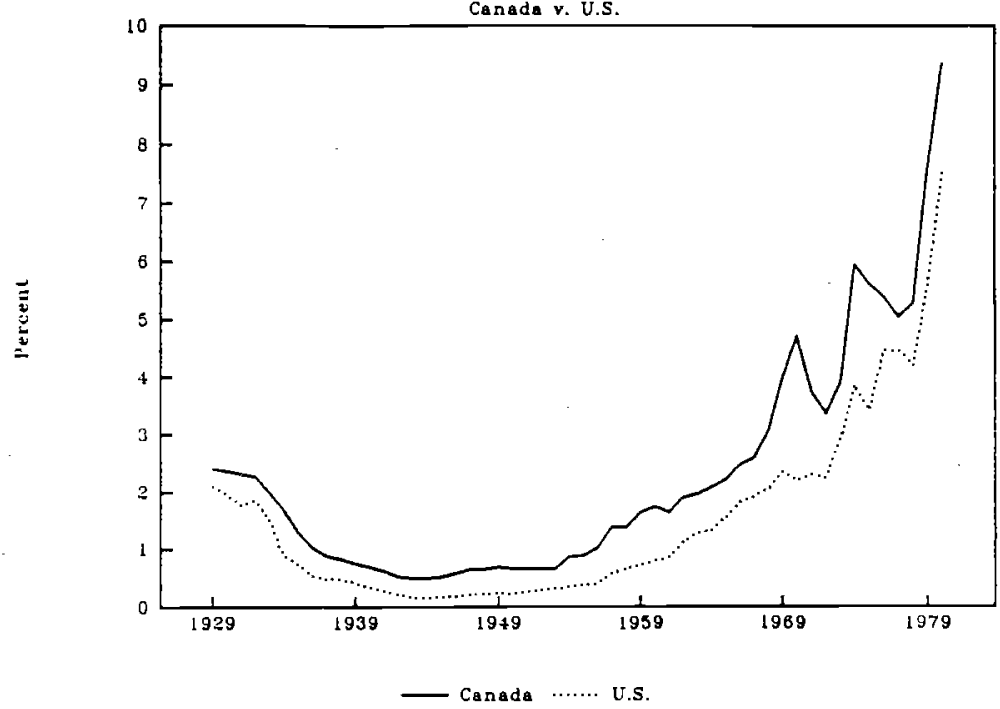

Figure 3B

Real Interest Rate on Deposits

Ceneda v. U.S.

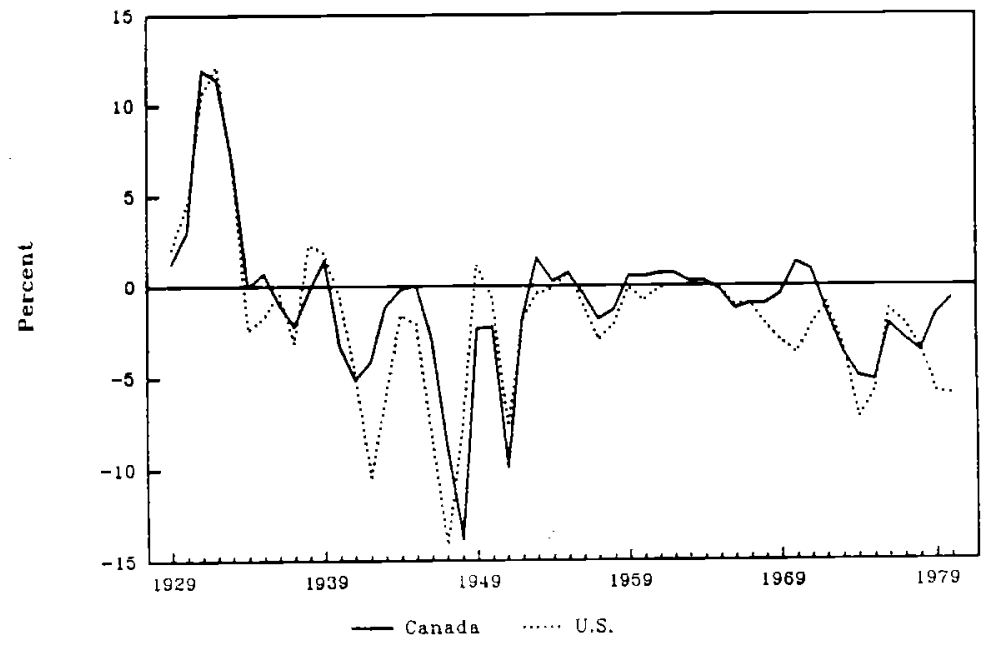


Figure $4 \mathrm{~A}$

Return on Loans

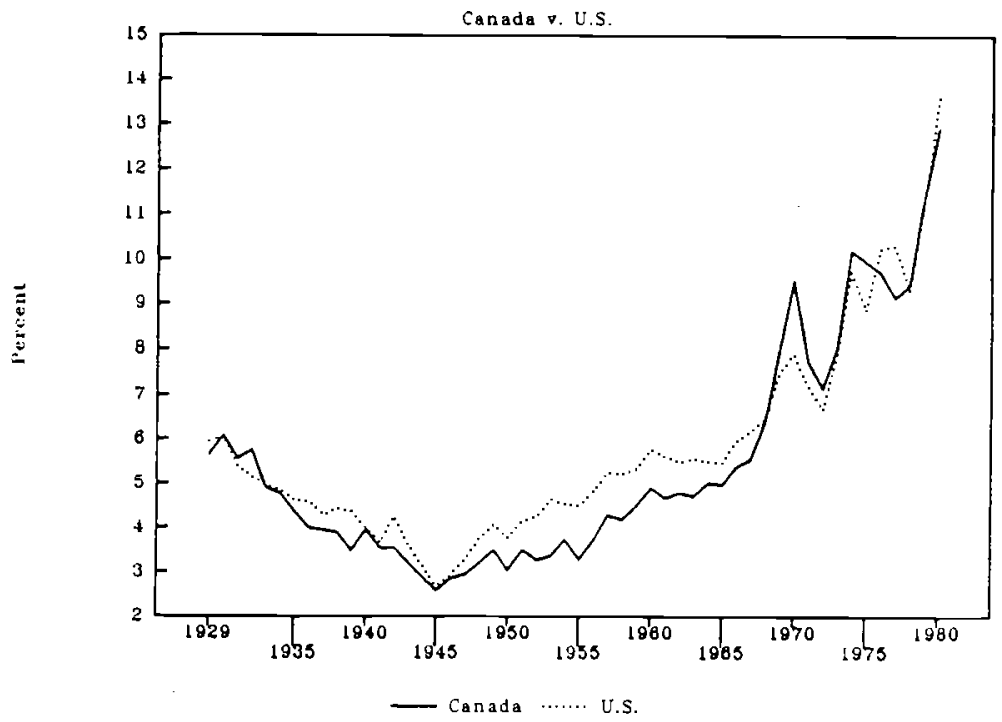

Figure $4 \mathrm{~B}$

Real Return on Loans

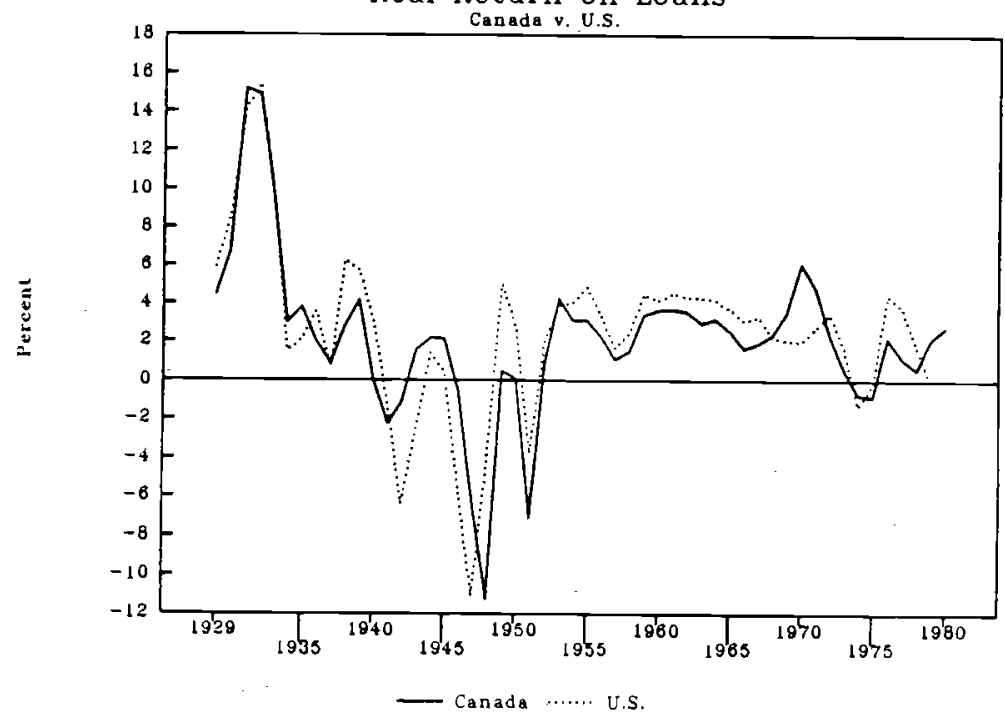


Figure 5A

Return on Securities

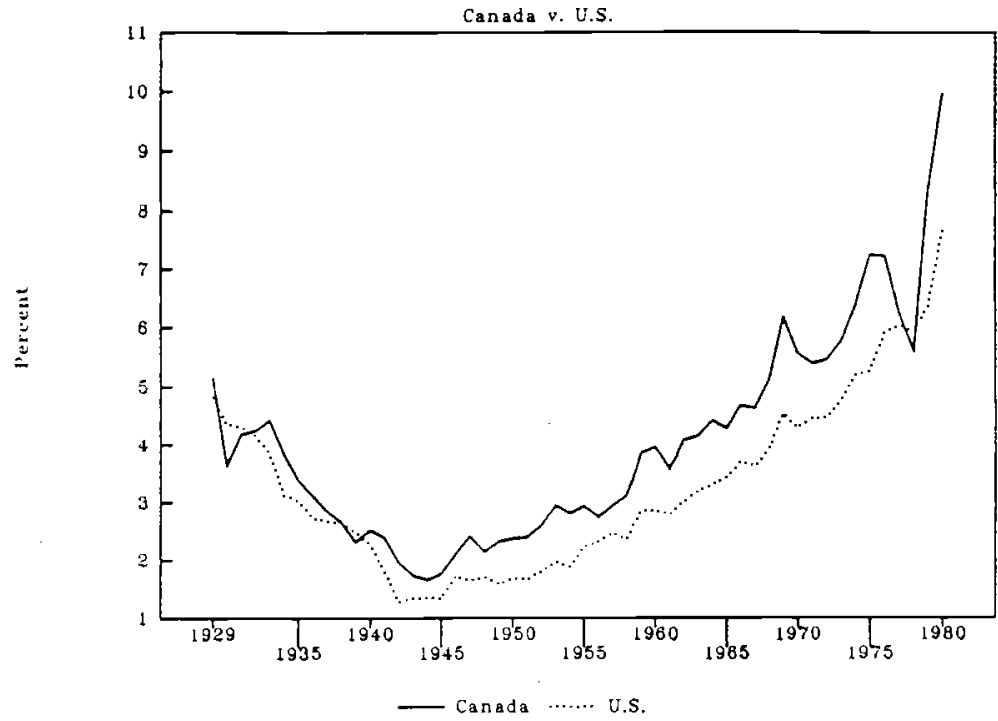

Figure 5B

Real Return on Securities

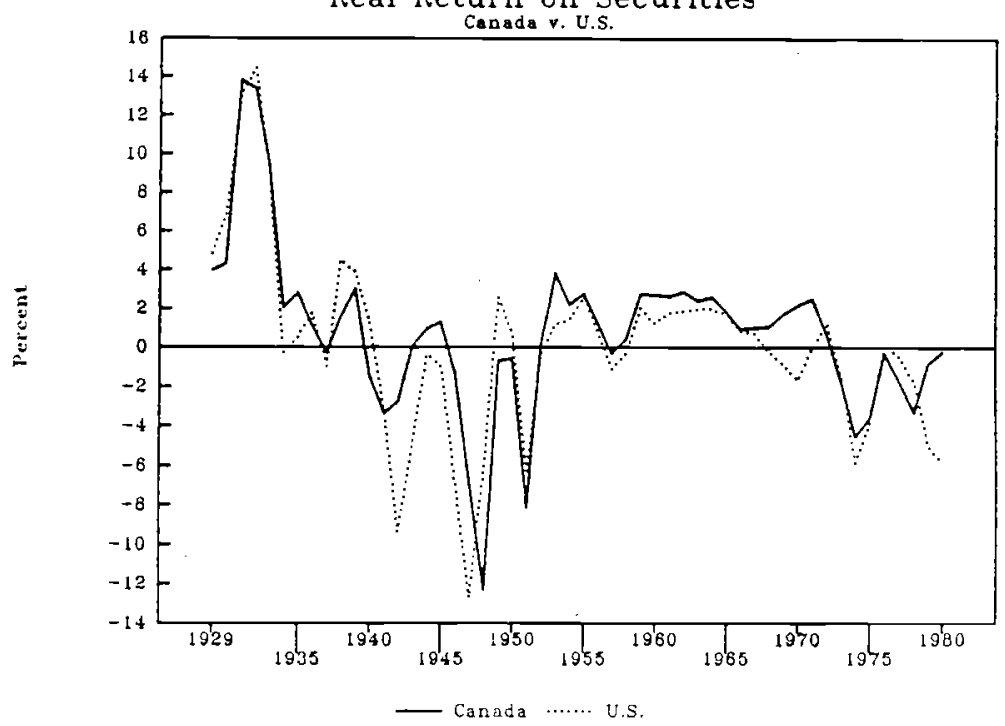


Figure 6A

Return on Equity

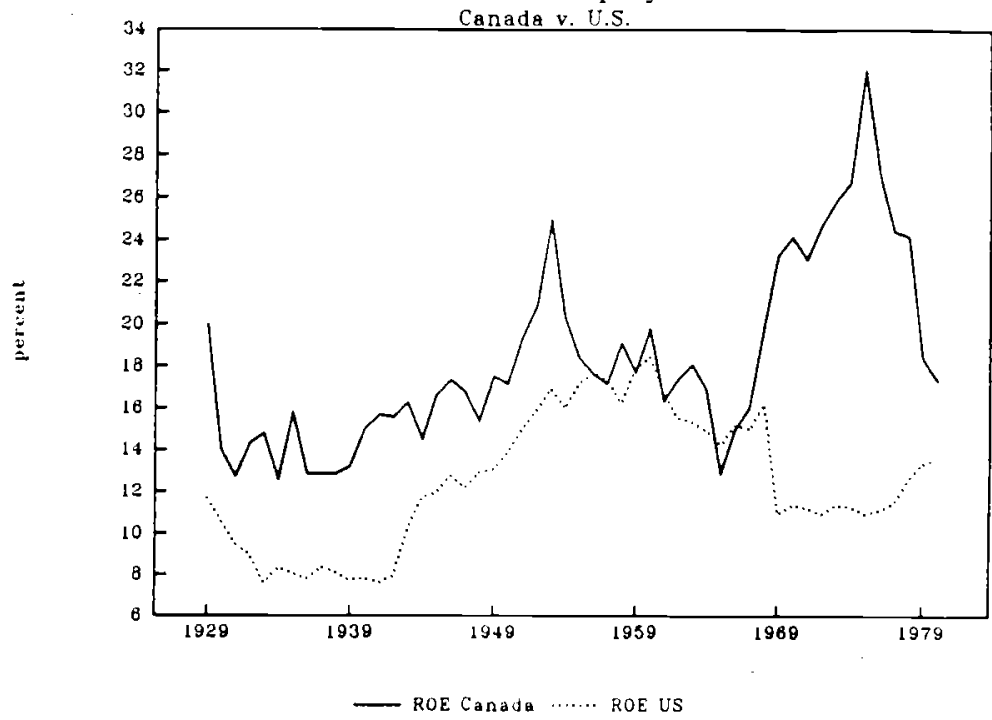

Figure 6B

Real Return on Equity

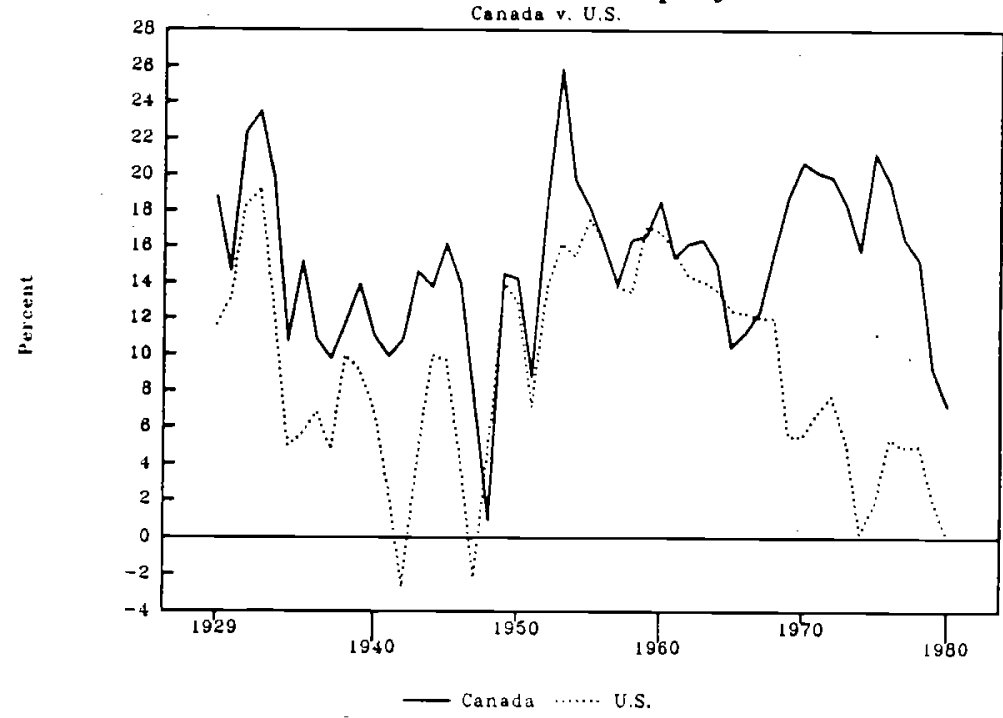


Figure $7 \mathrm{~A}$

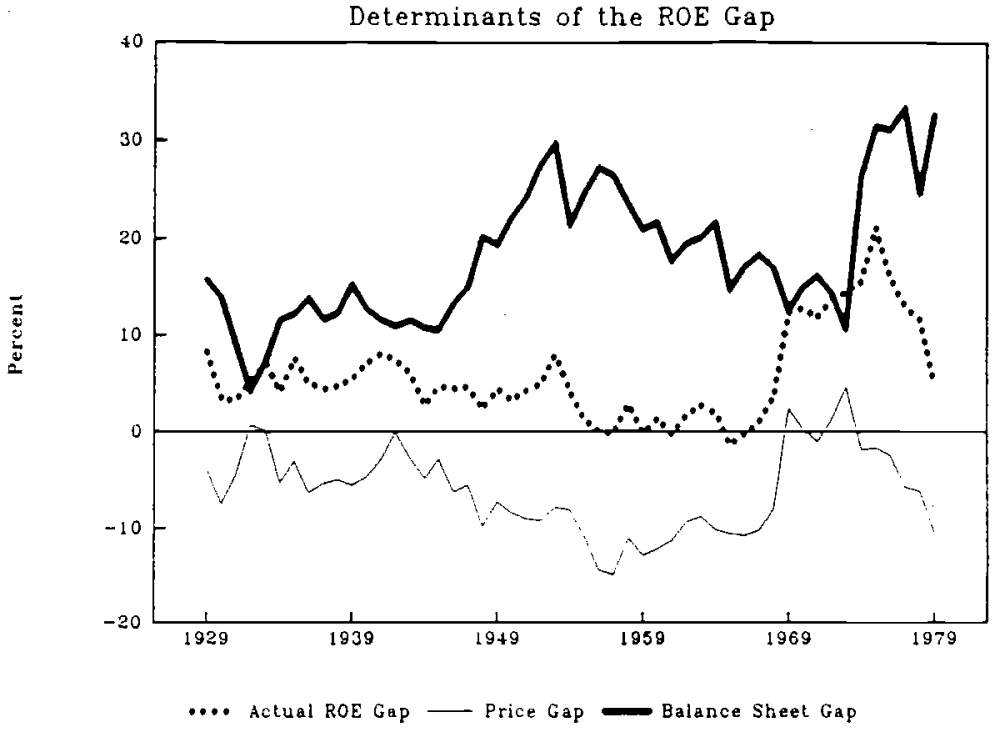

Figure 7B

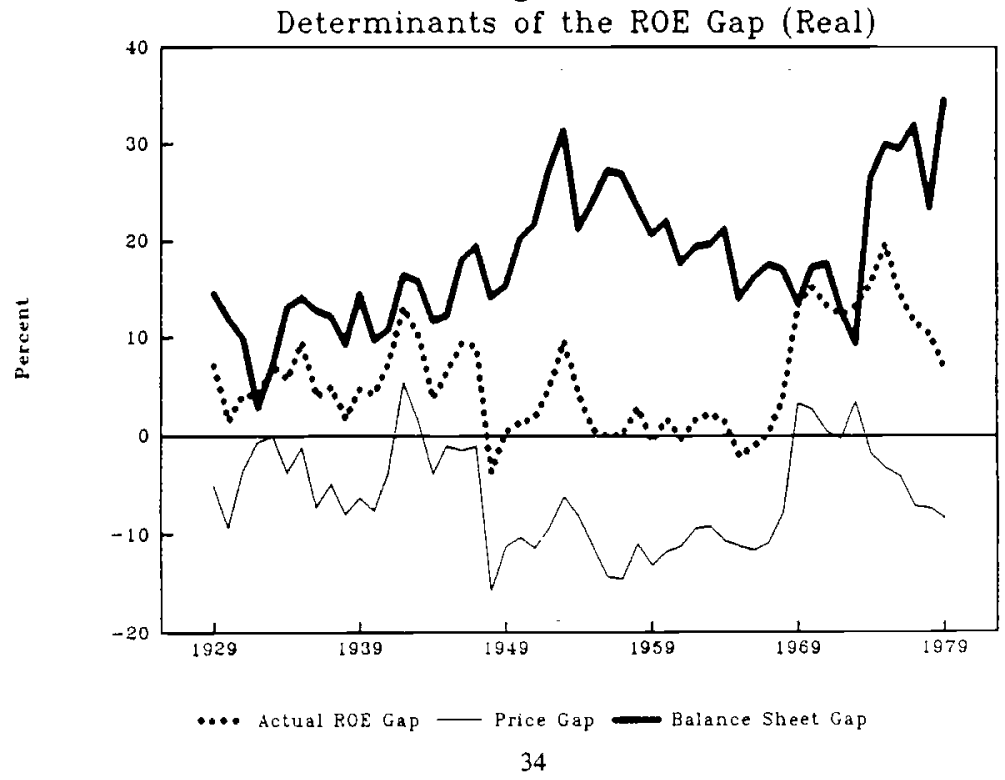

